\section{Seated Memory: New Insights into Near Eastern Neolithic Mortuary Variability from Tell Halula, Syria}

\author{
Emma Guerrero, Miquel Molist, Ian Kuijt, and Josep
} Anfruns

Department of Anthropology, 640 Flanner Hall, University of Notre Dame, Notre Dame, Indiana 46556, U.S.A. (emma.guerrerovila.1@nd.edu)/Departament de Prehistoria, Edifici B, Facultat de Lletres, Universitat Autonoma de Barcelona, 08193 Bellaterra (Barcelona), Spain (Molist, Anfruns)/Department of Anthropology, 617 Flanner Hall, University of Notre Dame, Notre Dame, Indiana 46556, U.S.A. (Kuijt) 6 X 08

\section{CA+ Online-Only Material: color version of figure 2}

Despite a long history of field research in the Neolithic of the Near East, archaeologists have a remarkably poor understanding of the degree of variation in mortuary practices within and between major Neolithic settlements. Such an understanding is critical for reconstructing the social, economic, and ritual interconnections between people in villages and, by extension, how researchers model social organization in early agricultural villages. Mortuary data from Middle PrePottery Neolithic B (PPNB) components of Tell Halula, a large Neolithic village in the middle valley of the Euphrates River, Syria, illustrate how household members buried their dead in standardized ways. These practices included burial of individuals only inside of buildings, in only one area of the main room, in single graves, and always in a fully upright, seated position. Houses were rebuilt in the same location, and rebuilding was always designed so that new houses had space for new burials. These residential buildings served as active spaces of life and death during the Pre-Pottery Neolithic at Tell Halula. Viewed collectively, the mortuary practices of Tell Halula are remarkably different from those of other contemporaneous Neolithic villages and challenge researchers to both document regional variation in shared cultural practices and model the social processes that contributed to shared regional practices and, simultaneously, to variation in how specific practices were enacted as events.

Between 10,500 and $9500 \mathrm{BP}$, the first early agricultural communities emerged in the Near East (fig. 1). People changed the way they organized their physical and social landscapes, and one of the most visible manifestations of this is seen with the appearance of Pre-Pottery Neolithic (PPN) villages. Often referred to by the term "Neolithic Revolution," the transition

(C) 2009 by The Wenner-Gren Foundation for Anthropological Research. All rights reserved. 0011-3204/2009/5003-0005\$10.00. DOI: 10.1086/ 598211 to the earliest villages was characterized by the aggregation of people into large villages, the appearance of domesticated plants and animals, and the reorganization of the social processes by which human interactions occurred. One aspect of this change is documented by excavations at PPN settlements: a range of formalized mortuary practices. Over the past 20 years, archaeological research at Middle PPNB settlements has revealed both a remarkable level of similarity in regional mortuary practices (see Kuijt 2008; Verhoeven 2002) and a high degree of variation in mortuary and ritual practices between individual settlements (e.g., Goring-Morris 2000; Hershkovitz and Gopher 1990; Kuijt 2008; Rollefson 1998; Rollefson, Schmandt-Besserat, and Rose 1999; Rollefson, Simmons, and Kafafi 1992; Verhoeven 2002). Interpretative modeling of these patterns has generally focused on understanding the nature of and variability within mortuary practices in individual communities or, alternatively, the degree to which mortuary practices were shared between regional communities.

Field excavations have documented elaborate mortuary practices that emerged out of sedentary villages with wellmade residential buildings, formalized lithic technology, and domesticated plants and animals. While researchers are starting to develop an understanding of regional practices, we have only a preliminary grasp of the extent of and reasons for variation in material practices within Middle PPNB settlements. In this paper, we present a general overview of the burial practices of the Middle PPN period at Tell Halula. Excavations at Tell Halula provide important new insights into Neolithic village organization as well as previously unrecognized levels of variation in social practices between villages.

\section{Tell Halula: Research Context and Background}

Tell Halula is located in the middle valley of the Euphrates River, $150 \mathrm{~km}$ from Aleppo in northern Syria. The site covers an area of 8 ha. Archaeological excavations from 1991 to 2007 have provided new understanding of the main periods of occupation and have documented village organization, architectural practices, the economic system, technological change, and social organization (Molist 1996, 1998, 2001; Molist et al. 2004). Broad horizontal excavations have allowed us to gain new insights into how space was organized by people at Tell Halula and how they disposed of their dead. As of 2007, excavations have allowed us to identify and recover 114 burials from 16 houses, all from the seventh through fourteenth occupation phases (fig. 2). ${ }^{1}$

Excavations have documented a succession of at least 20 different occupational events, largely defined by the construction/destruction of rectangular residential buildings. These buildings are made of mud brick and wooden beams, with

1. These were excavated between 1997 and 2005 and date to the end of the Middle PPNB and the beginning of the Late PPNB, or from 7500 to 7300 calibrated BC. 


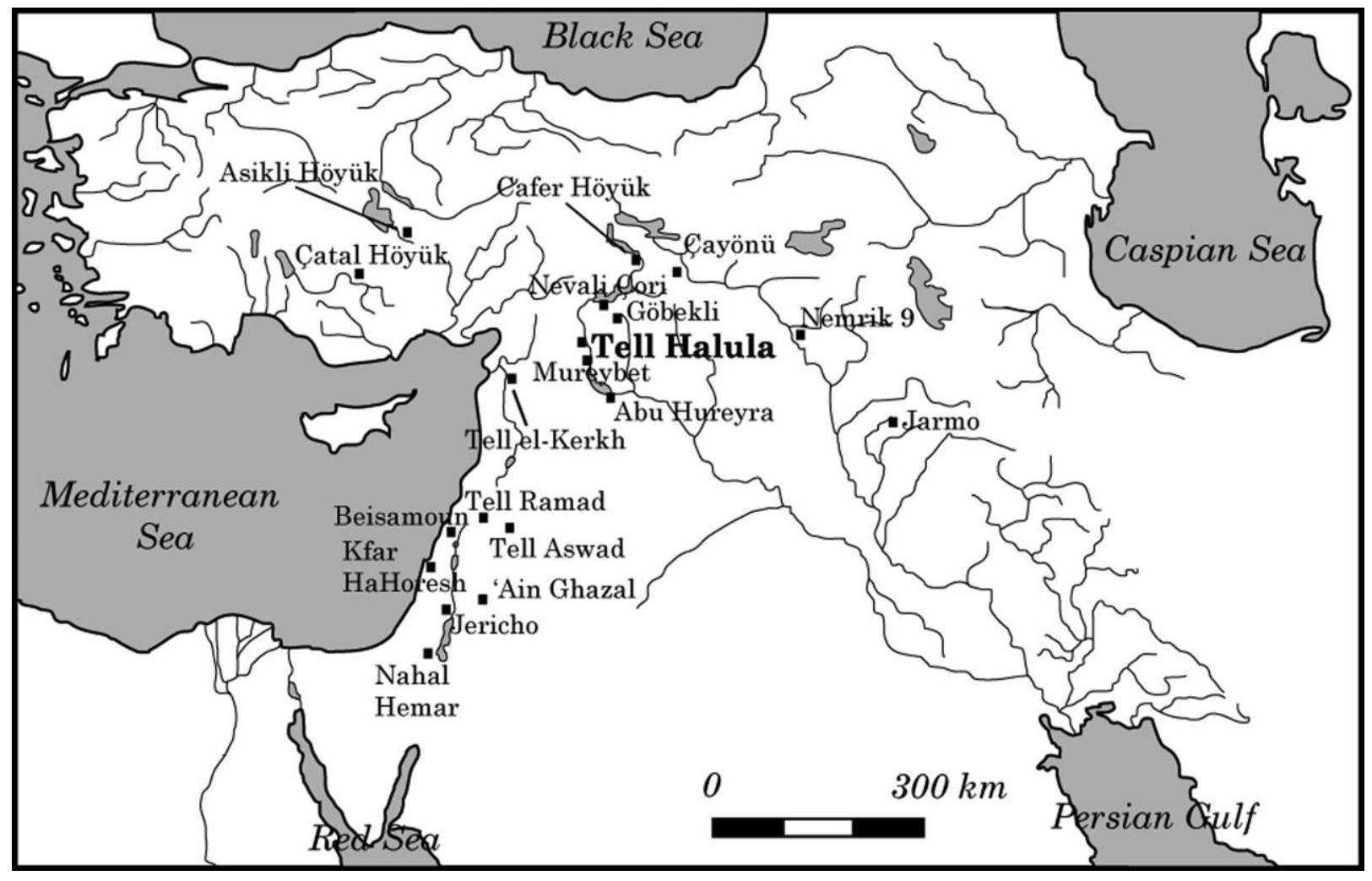

Figure 1. Location of Tell Hallula in relation to other large Middle and Late PPNB settlements.

lime to plaster the floors and the walls. Throughout these phases, residential buildings were placed in the same location, with one house parallel to another and spaced about $1 \mathrm{~m}$ apart.

All of these houses are rectangular and identical in organization, with three or four rooms (fig. 3). The main room consists of a large rectangular space (between 18 and $22 \mathrm{~m}^{2}$ ), with some of the floors and walls covered with a lime plaster. In some houses, these floors and walls are also painted. Domestic features in this main residential area often include a round or rectangular hearth, an oven with a flat cover, niches, benches, and drainage systems. At the far end of the building, away from the entranceway, there are usually two small rooms. The preparation of these rooms varies: sometimes they are plastered, but not always, and at times pit features and hearths are found in these rooms. It appears that these areas were used in multiple ways, including as storage areas, as an area for manufacturing tools, and possibly for drying and processing cereals. The entrance to each building is always located at the opposite end of the building, with a small patio or porch area in front of the doorway. This patio is physically defined by a more ephemeral wall system and often by a small inbuilt feature next to the door that might have served as a base for grain storage or a drying system (Molist 1996, 1998, 2001; Molist et al. 2004; fig. 4).

\section{Research Questions and Mortuary Analysis}

Previous excavations of Neolithic sites have documented variation in Neolithic mortuary practices between sites. It is much more difficult, however, to document the social, political, and economic processes that produced this variation. Even if they shared similar technologies, reliance on a mixture of domesticated and wild plants and animals, and ways of constructing residential buildings, people living in Neolithic communities in different locations did not always bury their dead in the same way. They placed the dead in different physical positions, buried them with different objects (or no objects at all), and probably followed different social rules for where the burials should be placed within their settlements.

While not always observable through material evidence, variation in mortuary practices provides insights into the degree of interconnection between people at multiple social scales, including household, village, and region. As a first step in this process, in this paper we provide a preliminary consideration of the relative variation in burial practices within and between houses at Tell Halula. To explore social life within Neolithic villages, we draw on data related to burial practices and architecture. To guide our discussion, we focus on the following questions. (1) How were burial practices spatially organized within the site and within individual structures? 


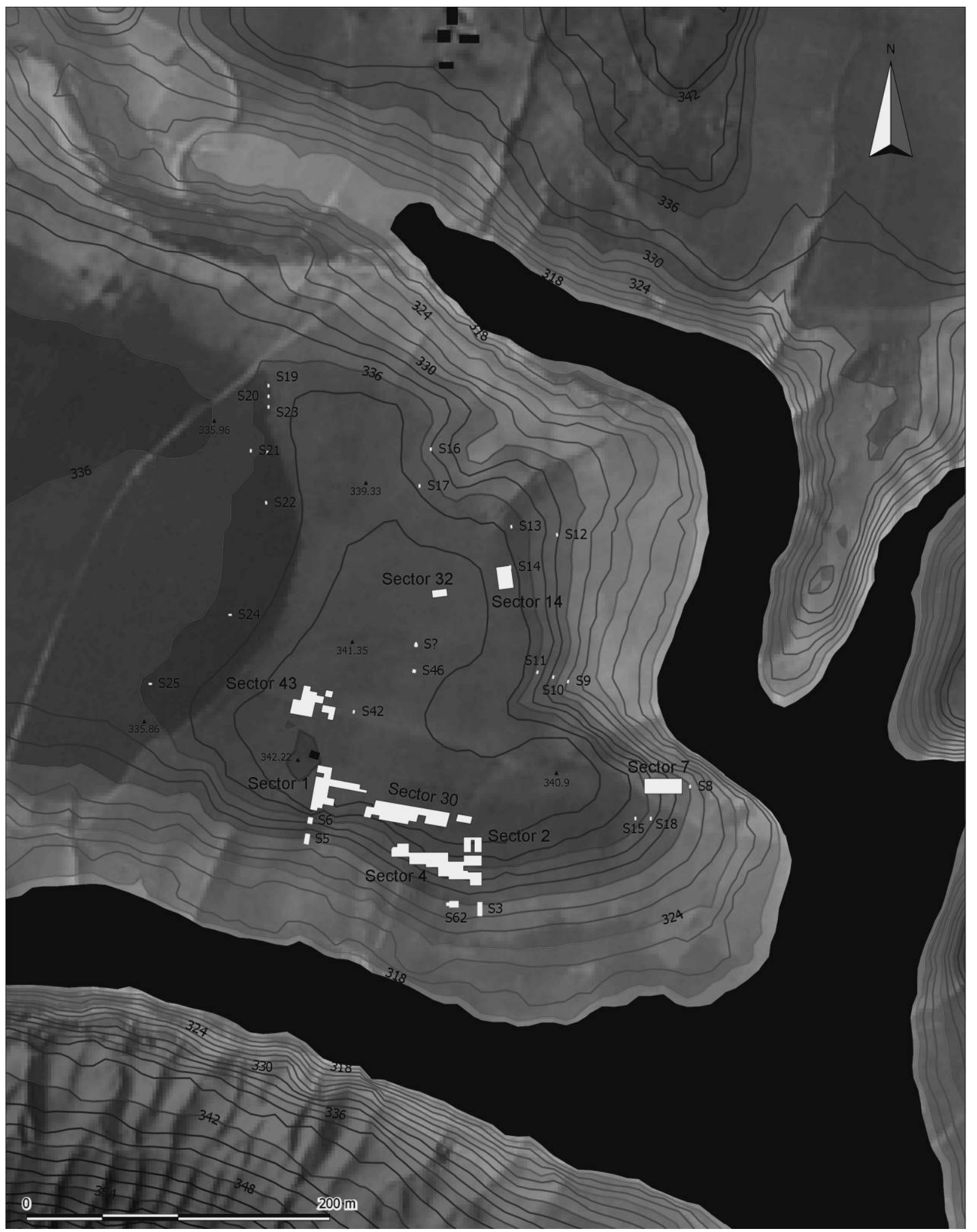

Figure 2. Excavation areas of Tell Halula. Note that the high water level is the result of a modern dam downstream. A color version of this figure is available in the online edition. 


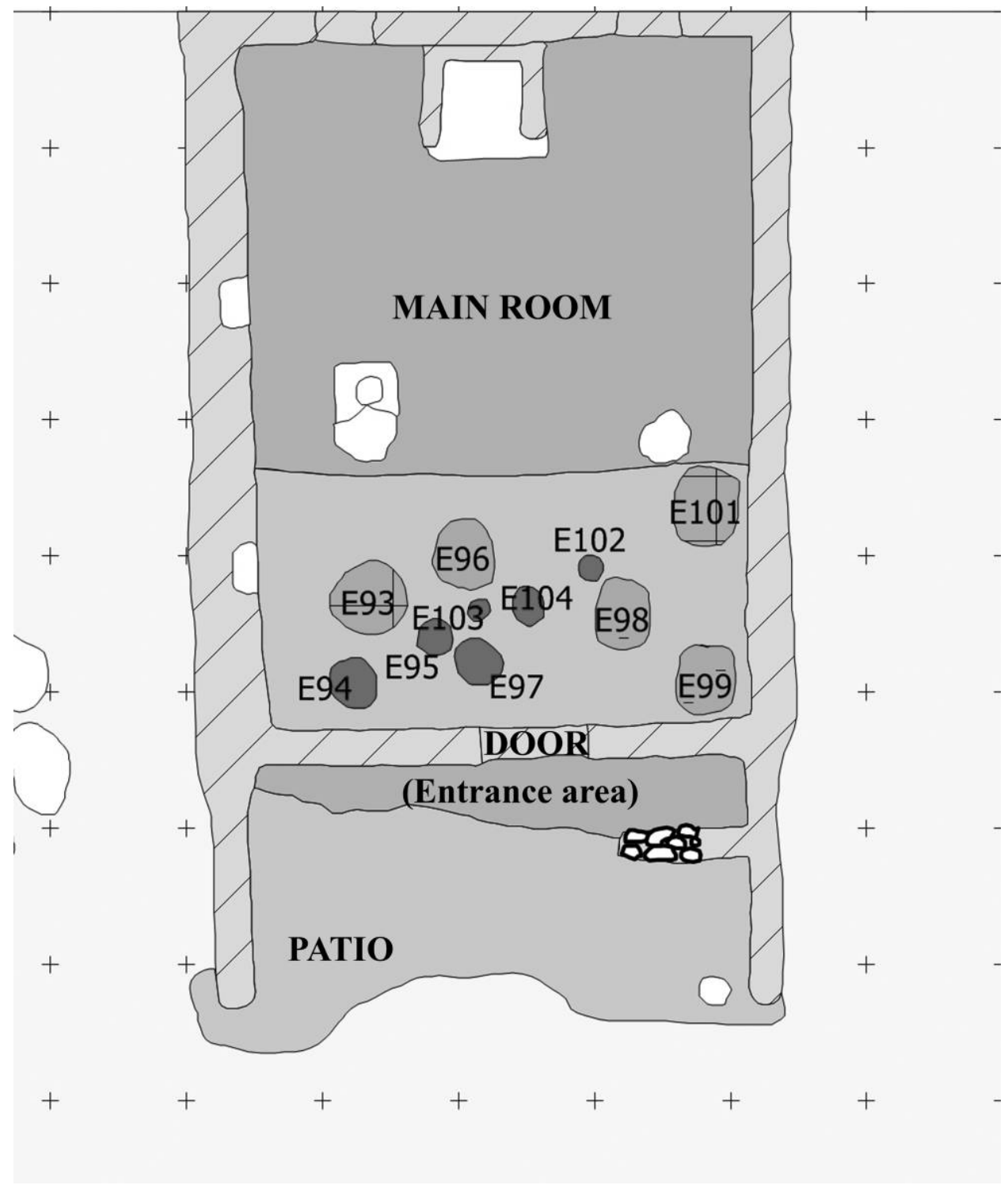

Figure 3. Plan view of complete house, showing typical internal organization. Areas labeled "E93"-"E104" indicate burials.

(2) Are there physical differences between where people were buried and the spaces used for intramural domestic activities? (3) To what extent would the burials have been visible to people living in these structures? (4) Was there any connection between the life history of individual houses, the rebuilding of houses, and burial practices?

\section{The Tell Halula House as Locus of the Living and the Dead}

Excavations at many Middle PPNB period sites illustrates that the dead were commonly buried in a wide range of intraand extramural locations. Comparison of Tell Halula with regional sites-such as Abu Hureyra, Mureybet, and Tell Ain el-Kerkh in Syria, Aşıklı, Çayönü, and Çatal Höyük in Turkey
(Akkermans and Schwartz 2003; Andrews, Molleson, and Boz 2005; Cauvin 1997; Esin and Harmankaya 1999; Moore and Molleson 2000; Özdoğan 1999; Verhoeven 2002), and many other sites in the southern Levant, including Jericho, 'Ain Ghazal, Yiftahel, Kfar HaHoresh, Ghwair I, Nahal Hemar, Munhata, Tell Aswad, Wadi Shu'eib, and Beidha-allow us to understand that between 10,500 and $9500 \mathrm{BP}$ people buried the dead in three areas of their settlements: in some form of shared repository, in a range of locations outside buildings, and inside residential buildings (Cornwall 1981; Goring-Morris 2000; Hershkovitz and Gopher 1990; Kirkbride 1968; Kuijt 2001, 2008; Kuijt and Goring-Morris 2002; Kurth and RöhrerErtl 1981; Rollefson 1998; Rollefson, Schmandt-Besserat, and 


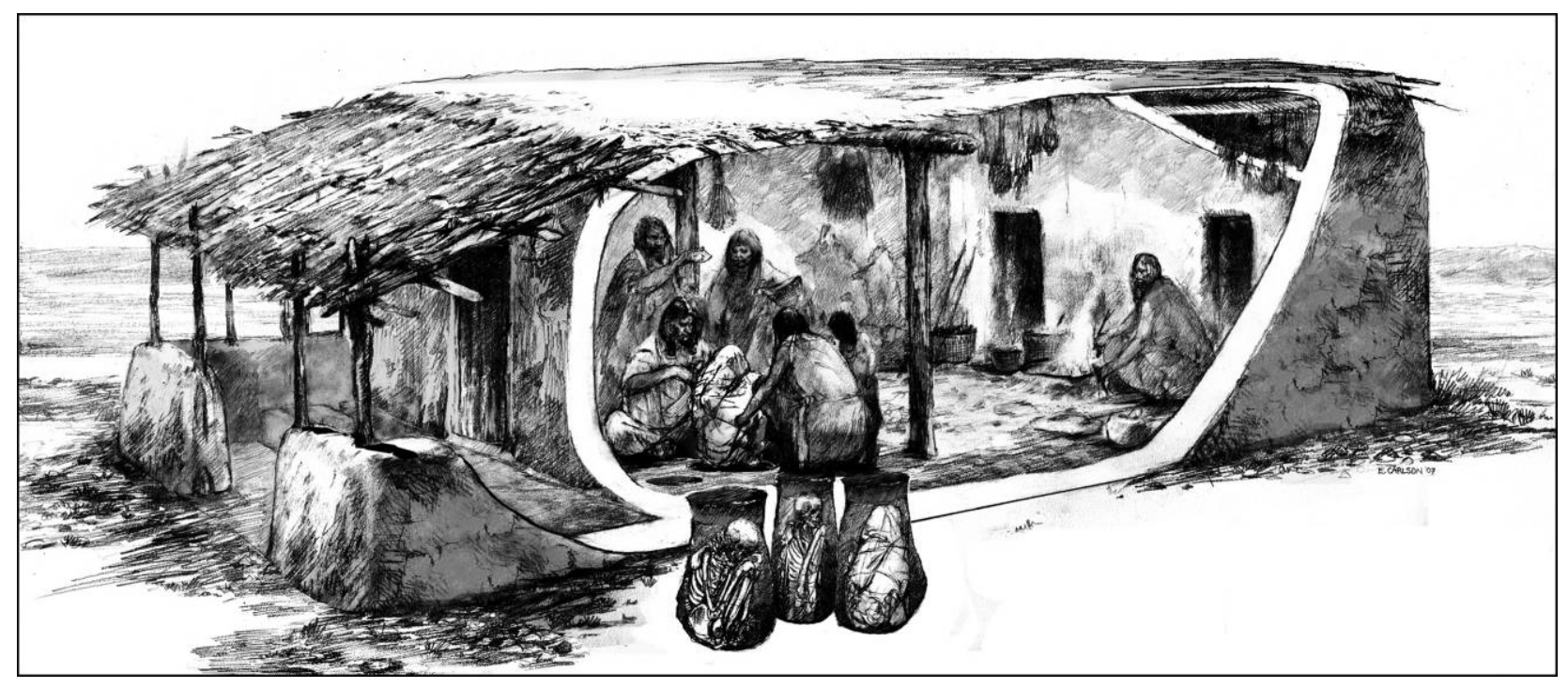

Figure 4. Reconstruction of a typical Middle PPNB house with burials being inserted in the burial area. Note the small enclosure in front of the entrance and the two rooms with small doorways at the far end of the building (illustration by E. Carlson).

Rose 1999; Rollefson, Simmons, and Kafafi 1992; Stordeur 2003).

At some settlements, both individual and collective burials were made in buildings built exclusively as a place for the dead. One example is the "skull building" at Çayönü, where 394 skeletons and some isolated skulls in secondary position, corresponding to 450 individuals, were found (Özdoğan 1999). At Abu Hureyra, there is also evidence of burials within most buildings and possibly the use of dedicated burial structures. While containing fewer individuals, the Abu Hureyra "charnel room" (room 3), at the northwest end of the house, served as a repository for the remains of at least 24 individuals, and pit 144, under the floor of room 2, contains the bones of 25-30 individuals (Moore and Molleson 2000). Even at later Neolithic sites, such as the main phases of Çatal Höyük that have been excavated, burials are more frequent in select buildings. Düring (2001) argues, for example, that a few special buildings, so-called ritually elaborated buildings, contain most of the burials, mounding, and paintings found, in contrast with the larger group of more ordinary and domestic buildings.

Most settlements dating from between 10,500 and $9500 \mathrm{BP}$, such as Abu Hureyra, burials were placed inside and outside of structures and in a range of rooms (Moore and Molleson 2000). Similarly, at 'Ain Ghazal and Jericho, the dead were buried below room floors, in courtyard areas, and under buildings (Kurth and Röhrer-Ertl 1981; Rollefson, Simmons, and Kafafi 1992). In Late PPNB sites, such as Çatal Höyük, burial practices were much more closely focused on placing the dead inside structures. It is not clear, however, whether this is because of much closer packing of residential archi- tecture, resulting in an almost complete lack of extramural space around individual buildings, or reflects a greater symbolic and ideological focus on the house as a place of action and history (Düring 2001; Kuijt 2008).

In contrast to what is seen at other Middle PPNB sites, at Tell Halula, all burials were placed inside structures. Of the 114 burials recovered from 16 houses and multiple phases of occupation over several hundred years, all of the burials were from subfloor pits inside the houses. Each of these burials is a primary individual interment, ${ }^{2}$ and there is only one case of secondary skull removal (figs. 5, 6). Over 16 years of fieldwork, we have excavated nearly $385 \mathrm{~m}^{2}$ of space between and around residential structures and have yet to identify a single burial. As seen in table 1 , data on the distribution of the number of burials among different houses and the location of burials illustrate a remarkable standardization of Neolithic burial practices at Tell Halula. We believe that this strong and repeated patterning and the fact that these practices were maintained for several hundred years reflect the development and maintenance of shared and clearly understood social practices for how the dead were dealt with. In these villages, people physically and symbolically linked the living with the dead, a link materialized within the house as a location of social practice.

2. The only exception is seen in burial 4I-E206 (house IB, trench 4I), which had two children interred in baskets, one of top of the other, inside a single adult-size grave. 


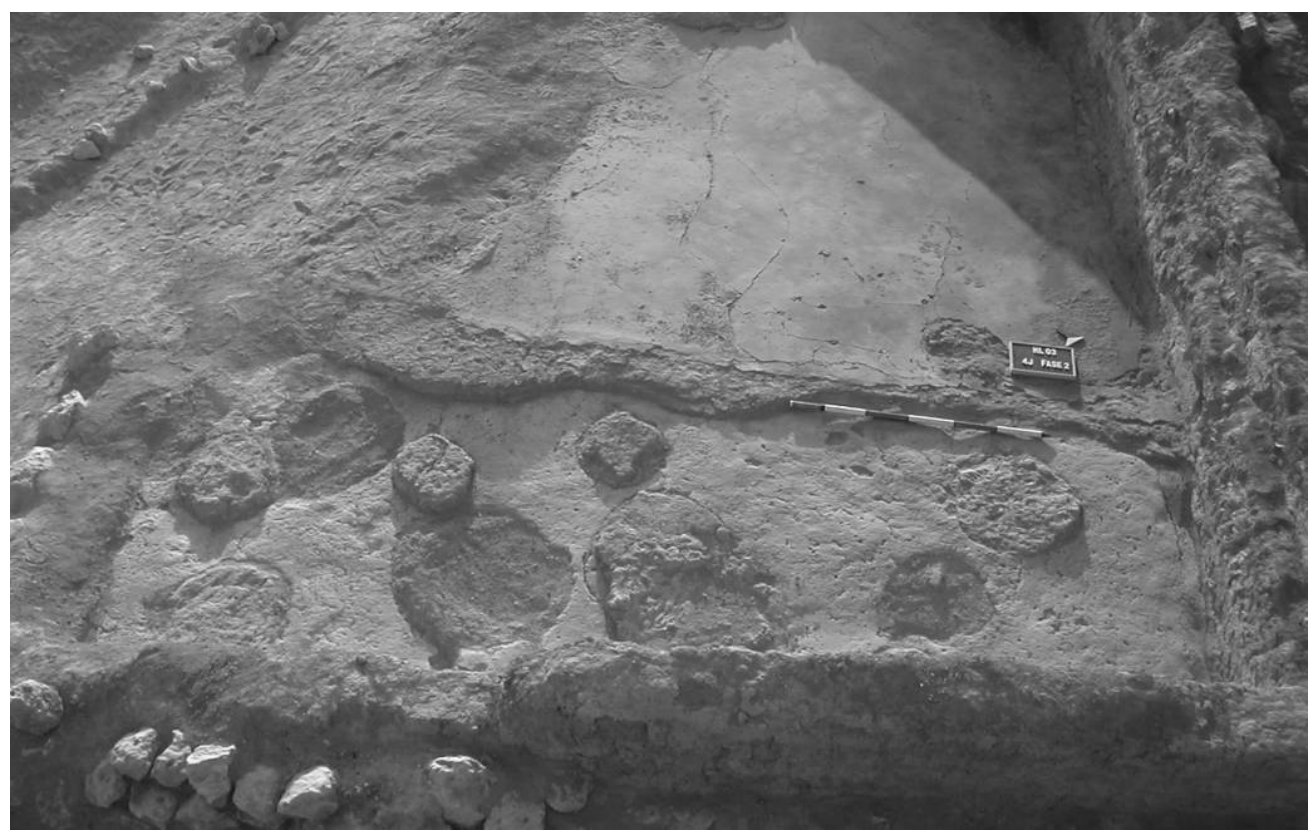

Figure 5. Typical burial area of a Middle PPNB Tell Halula house. Note the location of and the clay plug sealing each upright burial.

Order in the House: Where to Put the Dead?

In almost all cases (111/114), the burials at Tell Halula were placed near the entrance to the main room. ${ }^{3}$ The main room of the house can be symbolically and materially divided into two distinct areas enclosed by the same structural wall: what we call the "entrance/burial" area and the "main/domestic" area. In using these terms, we are not suggesting that people did not live or engage in domestic activities within the entrance/burial area of a house. We see no reason to suggest that people did not sleep, live, and engage in the same type of activities in both areas. Rather, we use these terms to outline some of the physical differences in floor construction and the spatial situating of select social acts that were materialized below the floor in one area of the larger room but not others.

The main/domestic area is enclosed by thick mud walls, a fire hearth/oven constructed opposite the entrance, and a floor made of multiple layers of plaster. Opposite the entrance are two small rooms probably used for storage and domestic goods. The main room is made possible structurally by two large posts supporting the roof. The entrance/burial area is defined physically by the use of an unfinished mud floor and symbolically by the placement of human burials in this area but not the rest of the room. As seen in figure 7, there is a noticeable difference between these floor treatments. As seen in table 1, these buildings were constructed so that there was

3. There are two exceptions to this pattern. In the twelfth phase of occupation in house FE/B, two burials were placed on each side of the oven, and in house $\mathrm{HC}$, two burials were placed in the northwestern corner of the main room. consistency in the area of the total entrance/burial space in the houses, as well as the percentage of space this represents of the total area of the main room. In most houses, the entrance/burial area represents about $34 \%$ of the total space of the main room, with house FE/C having the lowest percentage, at $25.2 \%$, and house $\mathrm{HE}$ having the highest percentage, at $42.1 \%$.

\section{Burial Placement and Life History}

Unlike burials in other Middle PPNB sites, the burials at Tell Halula are seated burials. With the exception of some fetal burials, the burials are flexed, with the legs pulled tightly up to the body and the arms folded around the chest (see fig. 6). Given the extraordinary preservation conditions of some of the burials, we can reconstruct the sequence of steps in the construction of the burial pits and the internment of the individuals. All of the burial pits were created in a similar way (see fig. 8). Initially, a circular-oval hole large enough to insert a burial was cut through the clay floor in the entrance area. Then the pit was extended downward by scooping out soil, often leaving straight walls, so that the pit was deep enough for the burial to be entirely below the floor. While there is variation, the base of the burial pit was often concave or flat. Next, the tightly flexed burial was lowered into the hole. Excavations have revealed that more than $50 \%$ of the pits still have empty spaces between the skeleton and the walls or are partially filled with very soft sediment. Less than $30 \%$ of the burial pits are filled with compacted sediment, suggesting that these pits were deliberately filled in when the 


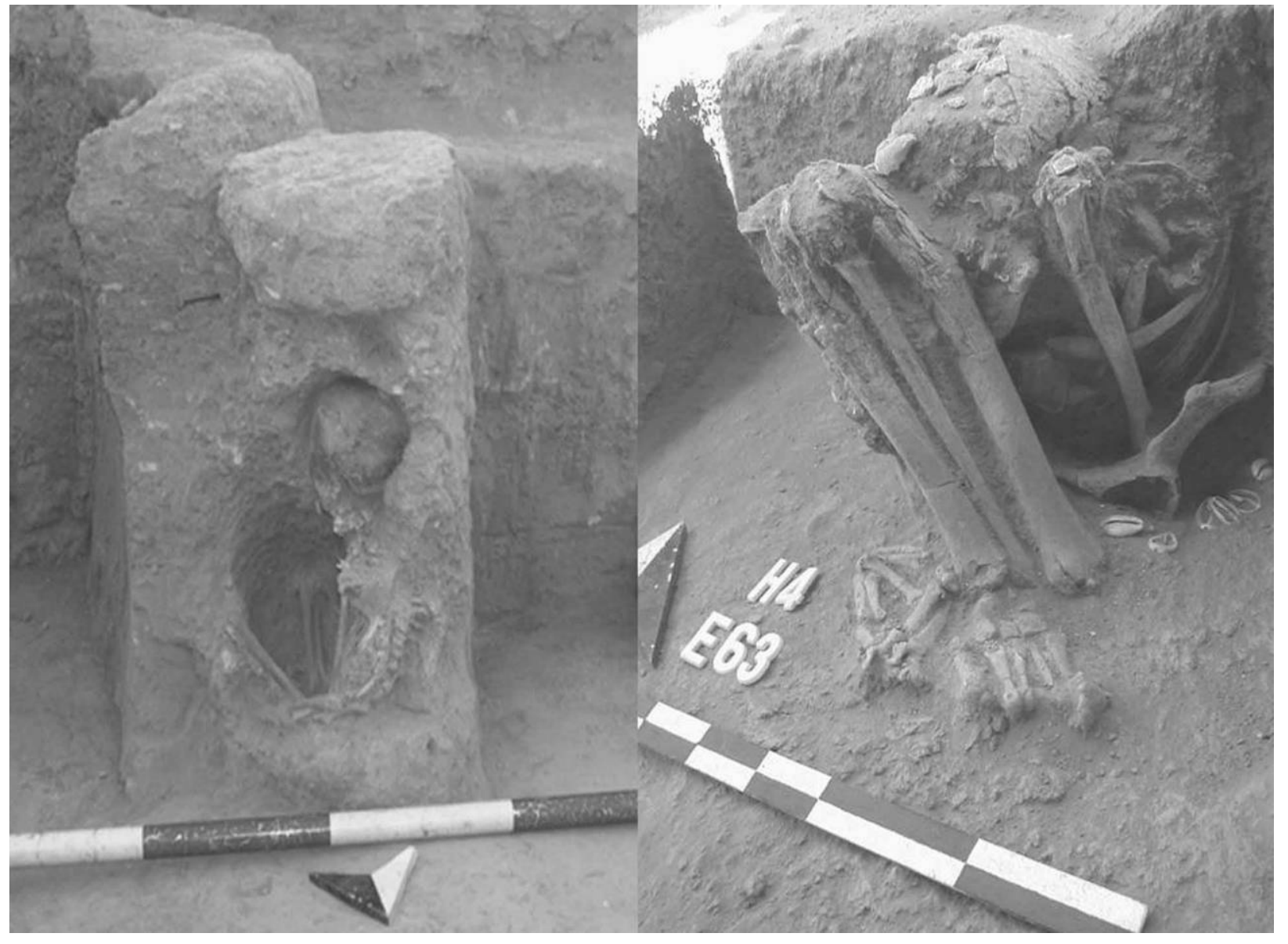

Figure 6. Typical Tell Halula seated burials. On the left, a child burial in cross section. On the right, an adult in flexed position, with the remains of a shell belt, after removal of surrounding dirt of the burial pit.

burial was inserted. Finally, people covered the opening of the pit with a compact mud plug that sealed the burial. This plug, much like a cork in a wine bottle, often extends down $20 \mathrm{~cm}$ into the opening. Where multiple burials had been inserted, the resulting appearance of the floor is a series of highly visible round patches (see fig. 5). People living in the house made no significant effort to disguise the location of individual burials by plastering over the floor after inserting the burial; instead, they appear to have deliberately left the floor unmodified. There is some limited evidence for reuse of a few burial pits, notably with the presence of some isolated bones and teeth from other individuals inside them. Most noticeably, there is one isolated skull (Anfruns and Molist 1996, 1998). It is unclear at this point, however, whether these exceptional cases reflect patterning of intentional secondary mortuary practices or unintentional postburial taphonomic processes related to rebuilding of houses.

As seen in table 2, reflooring was a regular part of living in houses. In house DD (trench $4 \mathrm{D}$, occupation phase 8 ), people living in the house put down five clay floors (E141,
E142, E144, E146, and E147), although burials have been found in only three (E141, E144, and E146). Excavations of house $\mathrm{HE}$ (trench $4 \mathrm{H}$, occupation phase 10) documented that people recovered the floor eight times (E143, E155, E160, E162, E165, E170, E173, and E174), with only six of these having burials. Thus, one or more frequently two burials were covered when people resurfaced the floor. Occasionally, the floor was replastered as routine maintenance or refurbishment of damaged floors.

\section{The Last Dance: Burial Dress, Coverings, and Ornamentation}

The outstanding dry preservation conditions provide researchers with important new insights into the materiality of Neolithic life at the point of death and, potentially, some of the social relations that characterized these villages. The excavation of many of the burial pits has uncovered organic remains of sacks, textiles, vegetable mats, and some basketry. Although the wrappings are only partially preserved, wrapping some or all of the body would have made it easier to insert 
Table 1. Burial distribution at Tell Halula by house and occupation phase (16 houses, 114 burials)

\begin{tabular}{|c|c|c|c|c|c|c|}
\hline House & Phase & $\begin{array}{l}\text { Building } \\
\text { preservation }^{\mathrm{a}}\end{array}$ & $\begin{array}{l}\text { No. } \\
\text { burials }\end{array}$ & $\begin{array}{l}\text { Total main room } \\
\text { area }\left(\mathrm{m}^{2}\right)\end{array}$ & $\begin{array}{l}\text { Entrance/burial } \\
\text { area }\left(\mathrm{m}^{2}\right)\end{array}$ & $\begin{array}{l}\% \text { of main room that is } \\
\text { entrance/burial space }\end{array}$ \\
\hline EXT & 14 & IC & 1 & & & \\
\hline IA & 13 & IC & 5 & & & \\
\hline JA & 13 & IC & 5 & & & \\
\hline $\mathrm{FE} / \mathrm{B}$ & 12 & IC & 2 & & & \\
\hline $\mathrm{HC}$ & 12 & $\mathrm{C}$ & 13 & 33.62 & 11.98 & 35.63 \\
\hline IB & 12 & IC & 8 & & & \\
\hline JB & 12 & $\mathrm{C}$ & 12 & 25.76 & 8.56 & 33.23 \\
\hline $\mathrm{HD}$ & 11 & $\mathrm{C}$ & 13 & 26.4 & 8.8 & 33.3 \\
\hline $\mathrm{FE} / \mathrm{C}$ & 11 & $\mathrm{C}$ & 13 & 43.7 & 11 & 25.17 \\
\hline $2 \mathrm{~A}$ & 11 & IC & 2 & & & \\
\hline DB & 10 & C & 9 & 18.97 & 6.37 & 33.58 \\
\hline $\mathrm{HE}$ & 10 & C & 9 & 22.08 & 9.3 & 42.12 \\
\hline DC & 9 & C & 13 & 19.05 & 7.06 & 37.06 \\
\hline $2 \mathrm{D} / 4 \mathrm{~B}$ & 9 & C & 3 & & & \\
\hline DD & 8 & C & 5 & 25.95 & 8.60 & 33.14 \\
\hline E27 & 7 & IC & 1 & & & \\
\hline
\end{tabular}

${ }^{\mathrm{a}} \mathrm{C}=$ complete; IC $=$ incomplete.

the burials into the relatively tight pits. It is also possible that some of the preserved organic material is from clothing as well as wrapping of the burials. The recovery of mat remains below the clay plug covering the burial, at times covering the skull of the individual, indicates that people first put down a layer of mats and then covered the opening with wet clay. Given that there is no evidence of burial pits overlapping others in houses, we argue that the inhabitants of Tell Halula used these clay plugs not only as a sanitary measure but also as a means of recording the exact location of the burials.

Our excavations have revealed that the majority of dead at Tell Halula were wearing some form of ornamentation when they were buried. Preliminary analysis indicates that, with varying frequencies, males and females, young and old were buried wearing objects and, in some cases, had objects placed in their graves when they were buried. Detailed analysis is ongoing, but preliminary research indicates that children up to 4 years have the great number of objects. Excavations reveal a wide range of objects interred with the dead, including ornamental objects such as stone and shell beads and bone pendants around the neck, around the waist, or next to the wrist. While not always in their original context, a number of well-preserved burials clearly show that some people were buried wearing necklaces, bracelets, and belts. Other objects, including shells, Byblos arrowheads, axes, bone needles, figurines, stone balls, and fragments of ocher, were also interred with burials.

\section{House Life Histories and Burials}

Structures at Tell Halula appear to have been rebuilt on a regular basis and, interestingly, directly above earlier structures. While excavations have yet to get to the lowest levels of the site, in some excavated areas of Tell Halula it is possible to identify five to seven rebuilding events, to a depth of at least 5-6 m. Each house is in the same location, and the Neolithic occupants rebuilt each structure about $0.70-0.80 \mathrm{~m}$ above the earlier one. This was probably done by pushing in the upper sections of the walls and importing soil to fill and level the remaining low areas so as to create a construction surface for the new building. It is important to note that there was sufficient fill between the floors of two buildings that subfloor burials from upper/more recent house did not penetrate into the floor of the lower/older house underneath. This is somewhat surprising, as it would have been much easier to use less fill between structures of different phases, despite the likelihood of disturbing earlier burials. This suggests that it must have been important for people who were rebuilding not to disturb family members who had lived and died when the earlier building was in use.

Unlike in other Neolithic sites, new burial pits do not cut into older burial pits. Each burial pit is separate and sealed. In some cases, buildings were rebuilt before all the floor area was used, but in all cases people maintained the integrity of individual burials. It is not clear why this happened. That people were buried only in the entranceway of the buildings, that they were spatially kept discrete from each other, and that buildings were deliberately reconstructed in such a way that a subfloor burial space was created all illustrate that Tell Halula villagers were actively concerned about maintaining the placement of the dead once they were buried. While not unheard of in other Neolithic cases, the standardization at Tell Halula is of a remarkably high degree.

Regional Comparison of Mortuary Practices between Tell Halula and Other Near Eastern Neolithic Sites

A number of important studies, including those of Bar-Yosef and Belfer-Cohen (1989) and Cauvin (1997), have looked at similar cultural practices, such as the adoption of rectilinear 


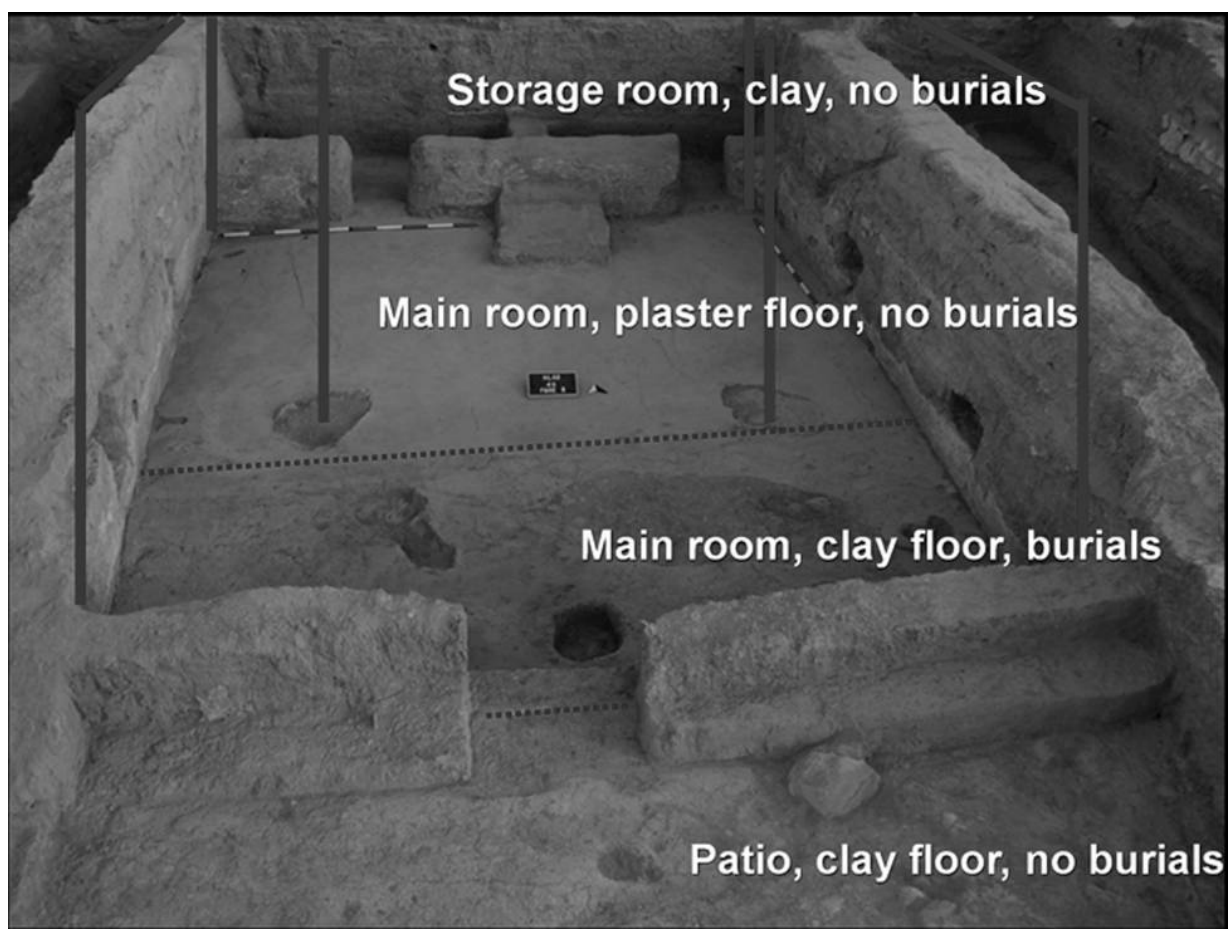

Figure 7. Oblique photo of house with inserted lines illustrating burial area, room features, and placement of other features.

buildings and the widespread use of animal and plant domesticates and have argued that people in Near Eastern Neolithic villages shared select key practices. While we agree with some of their arguments, other research (Asouti 2006; Kuijt 2004; Watkins 2008) has drawn attention to overlooked variability in cultural practices between members of different Neolithic communities and has called for increased debate as to the sources of variation at different scales. One, but by no means the only, example is the range of variation in burial practices in roughly contemporary settlements. We can see in table 3 that there was variation in the location of burials in the settlement, where people were buried within houses, how people were positioned, and the types of objects people were buried with.

Our preliminary analysis of the materials from Tell Halula, in comparison with those from other settlements, indicates that variation is greater between settlements than within settlements. For example, at Tell Halula, many people were buried with objects. This pattern is also seen at Aşıklı Höyük, Abu Hureyra, and Çatal Höyük. At other sites, most noticeably those from the southern Levant, people were rarely buried with objects. Other regional patterns highlight a wide range of burial locations. This included inside houses, in courtyard areas, and between buildings. As seen at Abu Hureyra, burials inside buildings were placed in almost every possible location: room corners, at the entrance of rooms, in back rooms, in front rooms. At all of the comparison settlements listed in table 3, people buried their dead in the same way: semiflexed, on their side or back, and in a range of locations.

The burial practices at Tell Halula are distinctly different from those in other excavated contemporary Middle PPNB settlements. At Tell Halula, people were buried only inside structures and only in the entrance/burial area. It is also important to note that burials are in a seated position. Our excavations have documented that this pattern does not vary between houses: it is the same regardless of house. This suggests that mortuary practices were widely shared, if not standardized, within the community and between households. The sharp contrast between the practices at Tell Halula and those at the Levantine comparison sites, such as Jericho and 'Ain Ghazal, can be rationalized as a function of geographical separation and regional differences. In fact, this might help explain the absence of grave goods in the Levantine sites. But how are we to explain the clear differences between Tell Halula and Abu Hureyra? Given the scale of excavations at these sites, it is difficult to view these differences as a by-product of sampling. Rather, the clear differences in burial practices reflect deliberate choices and the maintenance of distinctive practices at the community level. From this perspective, it is essential that, rather than envisioning Neolithic villages as part of a shared cultural system, such as an interaction sphere, archaeological and anthropological modeling recognize that some early agricultural villages existed as distinct communities with different material and symbolic practices. 


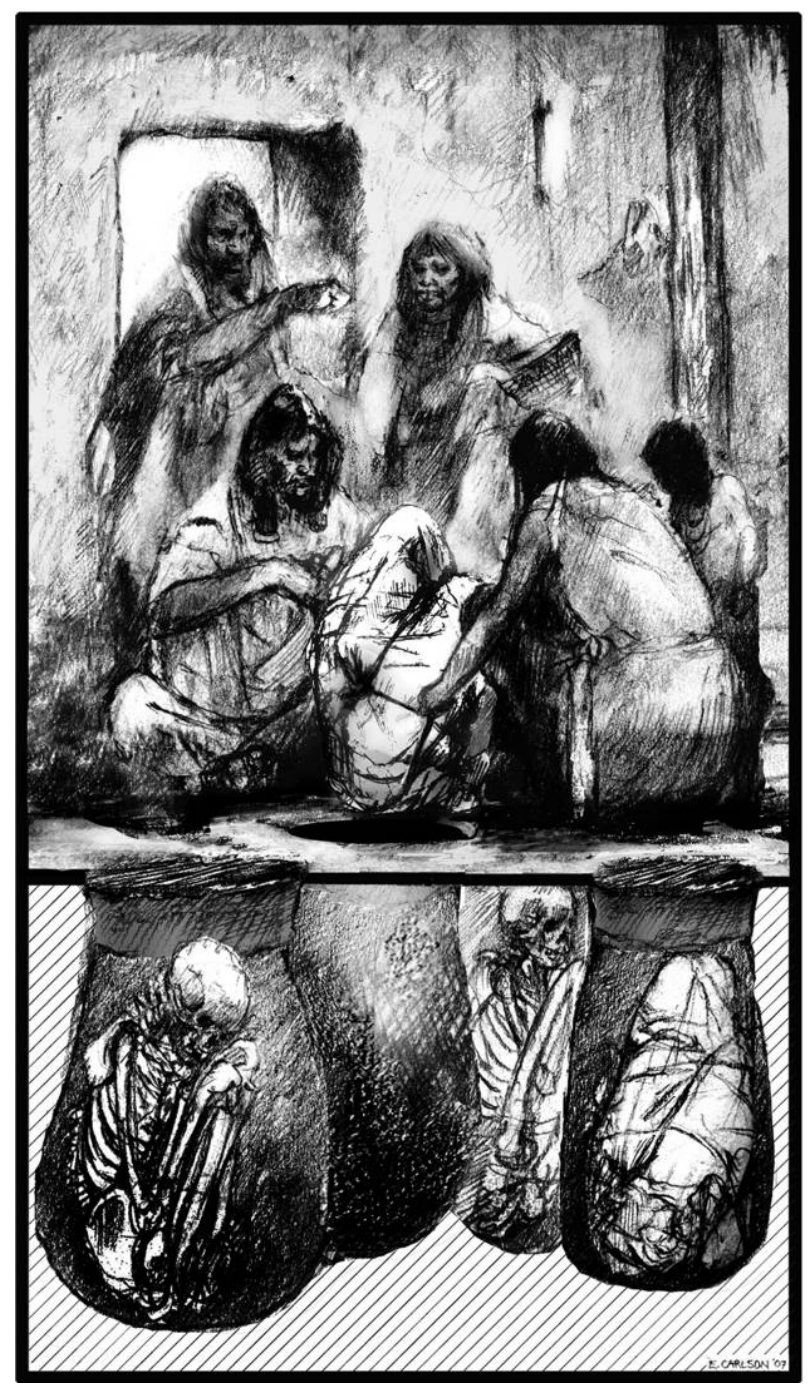

Figure 8. Reconstruction of burial being inserted into grave (illustration by E. Carlson). Note the typical placement of the individuals in bound and seated position, wrapped in cloth.

\section{Discussion and Conclusion}

Excavations at Tell Halula have outlined significant standardization in human practices within early Neolithic village communities, as well as documenting unanticipated levels of variation between regional settlements. All the buildings at Tell Halula are similar in design and size. All of them have a rectangular plan with one main room, two little rooms used for storage behind the main one, and a small "patio" in front, where some household production activities, such as food processing, were probably conducted. There is a clear standardization in the way people were buried and where they were placed for burial. The placement of burials at the only entrance into the building must have provided a visible reminder to visitors and occupants of the history and lineage of the family and house. To enter the house, visitors and owners would have had to literally walk over the previous house occupants. To look at it from a slightly different perspective, the dead were sleeping or living at the door of the house. As with the placement of medieval burials under tombstones of the great European cathedrals, the simple daily acts of movement into and out of the house would therefore have contributed to the reaffirmation of social memory, an understanding of lineage and social relations within households. Significant preplanning is seen in the village and household organization of Tell Halula. This patterning reflects a shared view of what constituted acceptable behaviors and treatment of the dead in different houses. This includes the use of clay floors instead of plaster floors in the burial/entrance area, the covering of the burials that allowed their visibility and avoided physical overlapping, and the standardized spatial distribution and location of the burials in the entrance area of all the houses.

Analysis of the Tell Halula burials highlights that, despite significant variation in the items associated with the dead, including what they were wearing and what was placed with them at burial, the overall system was highly formalized. Work is ongoing, but our preliminary analysis indicates that all age classes and both sexes were buried inside individual houses.

Table 2. Burial pits excavated in each of the clay floors documented at houses DD and HE

\begin{tabular}{lll}
\hline & \multicolumn{1}{c}{ Age } & \multicolumn{1}{c}{ Sex } \\
\hline House DD: & & \\
Floor E141: & & \\
Burial E130 & 18 years & Indeterminate \\
Burial E131 & 23 years & Male \\
Floor E142 & $\ldots$ & $\ldots$ \\
Floor E144: & $\ldots$ years & Female \\
Burial E132 & $>50$ years & Male \\
Burial E133 & & \\
Floor E146: & 5 years & Indeterminate \\
Burial E134 & & \\
Floor E147 & & \\
House HE: & & \\
Floor E143: & Child & Indeterminate \\
Burial E147 & Indeterminate & Indeterminate \\
Burial E150 & & \\
Floor E155: & Newborn & Indeterminate \\
Burial E156 & & \\
Floor E160: & & \\
Burial E161 & 11 years & Indeterminate \\
Burial E163 & Adult & Indeterminate \\
Floor E162: & & \\
Burial E171 & Child & Indeterminate \\
Floor E165: & & \\
Burial E157 & 3 years & Indeterminate \\
Burial E172 & 1 year & Indeterminate \\
Floor E170 & $\ldots$ & $\ldots$ \\
Floor E173 & $\ldots$ & $\ldots$ \\
Floor E174: & $\ldots$ months & \\
Burial E180 & & \\
\hline
\end{tabular}

Note. The burials are also distributed by the age and sex of individuals (although the definitive anthropological study of the human remains of house HE is incomplete). 


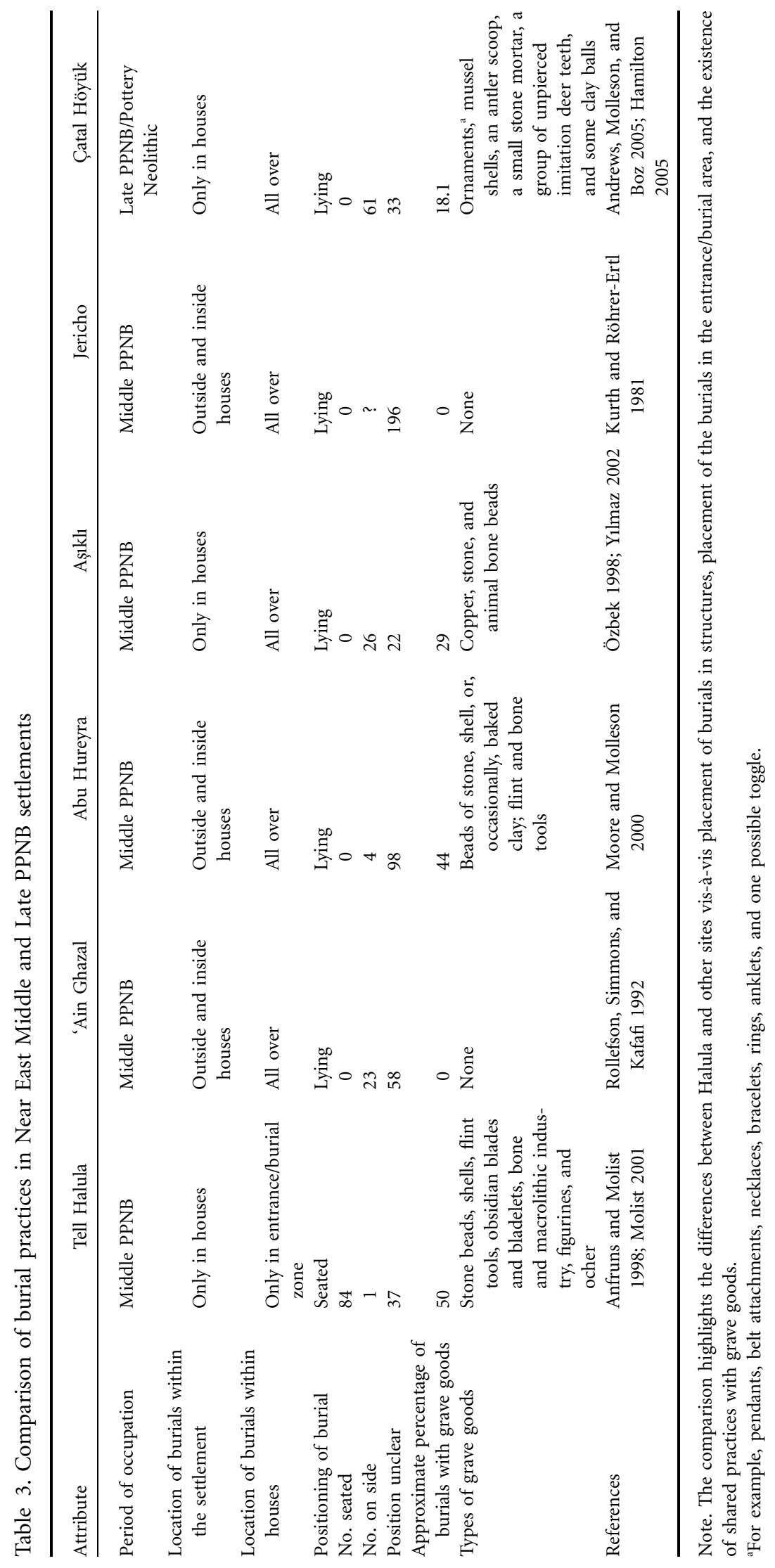


The number of burials found in each of the PPNB houses ranges from 5 to 13 , but within this there is variation in the ages and sex of burials. There is no evidence from Tell Halula of people burying the dead in specific age groups inside the houses or of the burying of some members of the population in specific buildings built only as burial spaces either within or outside the settlement. We therefore believe that the people living in a house probably belonged to the same social unit and that the inhumations found are a reflection of the familiar structure. Our ongoing analysis focuses on understanding whether people placed the dead in specific locations within houses, for example, separating the young from the old. Regardless of the possibility of such variation, each burial was treated in a similar way, as a single internment placed below the floor of the entrance/burial area of the house. This reflects a great regularity and standardization of the burial practices at the site.

This presentation of the Tell Halula data illustrates the urgent need for Near Eastern archaeologists to document and interpret the sources of Neolithic mortuary variation at multiple scales. At the household, we have illustrated how people engaged in similar burial practices within and between houses at Halula. Expanding on this, we have explored the remarkable standardization of burial practices at the community level at Tell Halula. Middle PPNB villagers and household members buried their dead in the same way in the same locations, presumably based on the same social rules. This involved highly formalized practices, and as seen with the rebuilding of houses through time, these practices were maintained over multiple generations. At the regional scale, researchers are only now starting to identify previously unrecognized levels of variation in mortuary practices between settlements. Whils other aspects of Neolithic life, such as stone tool technology, residential housing, and the use of domesticated plants and animals, reflect common and shared systems, the stark difference between mortuary practices of Tell Halula and those of other contemporary settlements highlights profound differences in how people viewed their worlds.

\section{Acknowledgments}

This paper expands on a written version of a paper presented at the Fifth International Congress on the Archaeology of the Ancient Near East, held in Madrid in April, 2006. The research project at Tell Halula, under the direction of Dr. Miquel Molist, is funded by the Dirección General de Bellas Artes/Instituto del Patrimonio Histórico Español (Program for Foreign Excavations). Some of the studies and analysis have been funded through the broader project "Cambio tecnológico, cambio social y proceso de Neolitización en el próximo or iente. Aportaciones de tres ámbitos ecológicos diferenciados: valle del Éufrates, Djezireh y oasis de Palmira" (HUM200766237, Ministry of Education and Science). Ian Kuijt thanks the Institute for Study in the Liberal Arts, the University of Notre Dame, and the National Endowment for the Human- ities. This paper was written while Emma Guerrero held an MAE-AECI (Ministry of Foreign Affairs-Spanish Agency for the International Cooperation) postdoctoral fellowship for the 2007-2008 academic year at the Department of Anthropology, University of Notre Dame. Finally, we would like to thank Eric Carlson for the great drawings in figures 4 and 8 .

\section{References Cited}

Akkermans, P. M. M. G., and G. M. Schwartz. 2003. The archaeology of Syria: from complex hunter-gatherers to early urban societies (ca. 16,000-300 BC). Cambridge: Cambridge University Press.

Andrews, P., T. Molleson, and B. Boz. 2005. The human burials at Çatalhöyük. In Inhabiting Çatalhöyük: reports from the 1995-99 seasons. I. Hodder, ed. Pp. 261-278. London: British Institute of Archaeology at Ankara.

Anfruns, J., and M. Molist. 1996. Estructuras de enterramiento y prácticas funerarias en Tell Halula: una primera aproximación. In Tell Halula (Siria): un yacimiento neolítico del Valle medio del Éufrates. M. Molist, ed. Pp. 151-160. Madrid: Instituto del Patrimonio Histórico Español.

- 1998. Prácticas funerarias en el neolítico de Siria: análisis de los documentos de Tell Halula (Valle del Éufrates). In El Mediterráneo en la antigüedad: oriente y occidente. Actas del I ${ }^{\circ}$ Congreso Español Antiguo Oriente Próximo (1997). J. L. Cunchillos, J. M. Galán, J. A. Zamora, and S. Villanueva, eds. Madrid: Centro de Estudios del Próximo Oriente (CEPO); Șapānu: Publicaciones en Internet del Laboratorio de Hermeneumática II.

$\rightarrow$ Asouti, E. 2006. Beyond the Pre-Pottery B interaction sphere. Journal of World Prehistory 20(2-4):87-126.

Bar-Yosef, O., and A. Belfer-Cohen. 1989. The Levantine "PPNB" interaction sphere. In People and culture in change: proceedings of the Second Symposium of Upper Paleolithic, Mesolithic, and Neolithic Populations of Europe and the Mediterranean Basin. I. Hershkovitz, ed. Pp. 59-72. BAR International Series 508. Oxford: British Archaeological Reports.

Cauvin, J. 1997. Naissance des divinités, naissance de l'agriculture: la révolution des symboles au Néolithique. Paris: Éditions du Centre National de la Recherche Scientifique.

Cornwall, I. W. 1981. Appendix A: the Pre-Pottery Neolithic burials. In Excavations at Jericho, vol. 3 of The architecture and stratigraphy of the Tell. K. M. Kenyon and T. A. Holland, eds. Pp. 395-406. London: British School of Archaeology in Jerusalem.

$\rightarrow$ Düring, B. 2001. Social dimensions in the architecture of Neolithic Çatalhöyük. Anatolian Studies 51:1-18.

Esin, U., and S. Harmankaya. 1999. Aşıklı. In Neolithic in Turkey: the cradle of civilization. New discoveries. M. Özdoğan and N. Başgelen, eds. Pp. 115-132. Istanbul: Arkeoloji ve Sanat Yayınları. 
Goring-Morris, N. 2000. The quick and dead: the social context of Aceramic Neolithic mortuary practices as seen from Kfar HaHoresh. In Life in Neolithic farming communities: social organization, identity, and differentiation. I. Kuijt, ed. Pp. 103-136. New York: Kluwer Academic/Plenum.

Hamilton, N. 2005. Social aspects of burial. In Inhabiting Çatalhöyük: reports from the 1995-99 seasons. I. Hodder, ed. Pp. 301-306. London: British Institute of Archaeology at Ankara.

Hershkovitz, I., and A. Gopher. 1990. Paleodemography, burial customs, and food-production economy at the beginning of the Holocene: a perspective from the southern Levant. Mitekufat Haeven: Journal of the Israel Prehistoric Society 23:9-48.

Kirkbride, D. 1968. Beidha 1967: an interim report. Palestine Exploration Quarterly 100:90-96.

Kuijt, I. 2001. Meaningful masks: place, death, and the transmission of social memory in early agricultural communities of the Near Eastern Pre-Pottery Neolithic. In Social memory, identity, and death: intradisciplinary perspectives on mortuary rituals. M. S. Chesson, ed. Pp. 80-99. Archaeological Papers 10. Washington, DC: American Anthropological Association.

— 2004. Cyprus as a regional Neolithic entity: do researchers need to revisit the concept of the Levantine PPNB interaction sphere? Neo-Lithics 1(4):8-9.

$\rightarrow-$. 2008. The regeneration of life: Neolithic structures of symbolic remembering and forgetting. Current Anthropology 49(2):171-197.

$\rightarrow$ Kuijt, I., and N. Goring-Morris. 2002. Foraging, farming, and social complexity in the Pre-Pottery Neolithic of the southern Levant: a review and synthesis. Journal of World Prehistory 16(4):361-440.

Kurth, G., and G. Röhrer-Ertl. 1981. On the anthropology of Mesolithic to Calcolithic human remains from the Tell esSultan to Jericho, Jordan. In Excavations at Jericho, vol. s of The architecture and stratigraphy of the Tell. K. M. Kenyon and T. A. Holland, eds. Pp. 407-499. London: British School of Archaeology in Jerusalem.

Molist, M., ed. 1996. Tell Halula (Siria): un yacimiento neolítico del Valle medio del Éufrates: campañas de 1991-1992. Madrid: Instituto del Patrimonio Histórico Español. . 1998. Espace collectif et espace domestique dans le néolithique des Xème et VIIIème millénaires B. P. au norc. de la Syrie: apports du site de Tell Halula (Vallée de l'Euphrate). In Espace naturel, espace habité en Syrie du Nord $\left(10^{\mathrm{e}}-2^{\mathrm{e}}\right.$ millénaires av. J-C.): actes du colloque tenu à l'Université Laval (Québec) du 5 au 7 mai 1997. M. Fortin and O. Aurenche, eds. Pp. 115-130. Bulletin of the Canadian Society for Mesopotamian Studies 33; Travaux de la Maison de l'Orient 28. Québec: Canadian Society for Mesopotamian Studies; Lyon: Maison de l'Orient Méditeranéen.

- 2001. Halula, village néolithique en Syrie du Nord. In Communautés villageoises du Proche Orient à l'Atlantique (8000-2000 avant notre ère). J. Guilaine, ed. Pp. 35-52. Paris: Editions Errance.

Molist, M., J. Anfruns, W. Cruells, X. Clop, and M. Saña. 2004. Estudio del asentamiento de Tell Halula (Valle del Éufrates, Siria): aportaciones para el estudio de la emergencia de las sociedades agrícolas en el Próximo Oriente. Bienes Culturales 3:45-62.

Moore, A. M. T., and T. I. Molleson. 2000. Disposal of the dead. In Village on the Euphrates: from foraging to farming at Abu Hureyra. A. M. T. Moore, G. C. Hillman, and A. J. Legge, eds. Pp. 277-299. New York: Oxford University Press.

Özbek, M. 1998. Human skeletal remains from Aşıklı, a Neolithic village near Aksaray, Turkey. In Light on top of the Black Hill: studies presented to Halet Çambel. G. Arsebük, M. J. Mellink, and W. Schirmer, eds. Pp. 567-579. Istanbul: Ege Yayınları.

Özdoğan, A. 1999. Çayönü. In Neolithic in Turkey: the cradle of civilization. New discoveries. M. Özdoğan and N. Başgelen, eds. Pp. 35-63. Istanbul: Arkeoloji ve Sanat Yayınları.

Rollefson, G. O. 1998. The Aceramic Neolithic. In The prehistoric archaeology of Jordan. D. O. Henry, ed. Pp. 102-126. British Archaeological Reports 705. Oxford: Archaeopress.

Rollefson, G. O., D. Schmandt-Besserat, and J. C. Rose. 1999. A decorated skull from MPPNB 'Ain Ghazal. Paléorient 24: 99-104.

$\rightarrow$ Rollefson, G. O., A. H. Simmons, and Z. Kafafi. 1992. Neolithic cultures at 'Ain Ghazal, Jordan. Journal of Field Archaeology 19:443-470.

Stordeur, D. 2003. Tell Aswad: résultats préliminaires des campagnes 2001 et 2002. Neo-Lithics 1(3):7-15.

$\rightarrow$ Verhoeven, M. 2002. Ritual and ideology in the Pre-Pottery Neolithic B of the Levant and southeast Anatolia. Cambridge Archaeological Journal 12(2):233-258.

$\rightarrow$ Watkins, T. 2008. Supra-regional networks in the Neolithic of southwest Asia. Journal of World Prehistory 21:139-171.

Yılmaz, Y. 2002. Aşıklı Höyük iskeletlerinin morfologik olarak karşılaştırmalı incelenmesi. MA thesis, University of Istanbul. 